\title{
Lehmälle oma vai jaettu ruokintapaikka?
}

Satu Raussi ${ }^{1)}$, Päivi Mäntysaari ${ }^{1)}$, Lauri Jauhiainen ${ }^{2)}$, Jutta Siivonen ${ }^{1)}$, Leena Tuomisto ${ }^{3)}$, Kaisa Räsänen ${ }^{4)}$ ja Marketta Rinne ${ }^{1)}$

${ }^{1)}$ MTT, Kotieläintuotannon tutkimus, 31600 JOKIOINEN, etunimi.sukunimi@mtt.fi

${ }^{2)}$ MTT, Palveluyksiköt, 31600 JOKIOINEN, etunimi.sukunimi@mtt.fi

3) MTT, Kotieläintuotannon tutkimus, Halolantie 31 A, 71750 MAANINKA, etunimi.sukunimi@mtt.fi

4) Hämeen Ammattikorkeakoulu, Mustialantie 105, 31310 MUSTIALA

\section{Tiivistelmä}

Karkearehun ruokintapaikkojen määrä on usein pihatoissa rajoitettu, eivätkä kaikki lehmät mahdu syömään samanaikaisesti. Lehmillä on kuitenkin luontainen taipumus syödä yhtä aikaa, varsinkin uuden rehun jaon jälkeen ruokintapöydällä on tungosta. Tutkimme ruokintapöytäpaikkojen rajoittamista MTT:n Minkiön pihatossa. Selvitimme myös lehmän poikimakerran ja väkirehunruokintatason nostamisen vaikutukset lehmien tuotantoon, syöntiin ja käyttäytymiseen.

Kokeessamme oli 36 ayrshire-lehmää, joista 12 oli ensikoita. Lehmillä oli puolet koeajasta oma ja puolet ajasta kahden muun lehmän kesken jaettu säilörehun syöntipaikka. Jaetulla paikalla oli 1 ensikko, 1 kaksi ja 1 kolme kertaa poikinut lehmä. Kaikilla ruokintapaikoilla oli tarjolla hyvälaatuista säilörehua vapaasti. Väkirehuruokintatasoja oli kaksi; puolella lehmistä oli koko kokeen ajan rehuannoksen kuiva-aineesta $45 \%$ ja puolella 57 \% väkirehua. Väkirehu tarjottiin väkirehukioskeista sekä lypsypaikalta. Koe toteutettiin kahdessa 4 viikon jaksossa cross over-kokeena ruokintapaikkojen suhteen. Jaksolla 2 lehmät, joilla jaksolla 1 oli oma ruokintapaikka, jakoivat paikan kahden muun lehmän kanssa ja jaksolla 1 jaetulla paikalla olleet saivat omat paikat.

Jaksojen viimeisillä viikoilla rekisteröitiin maitomäärä jokaiselta lypsykerralta ja maitonäytteet neljältä lypsykerralta. Eläinkohtaiset väkirehun syöntimäärät kirjautuivat automaattisesti kioskeista ja säilörehun syöntimäärät, -kerrat ja -ajat vaakakupeista. Eläinten käyttäytyminen rekisteröitiin neljänä päivänä molemmilla jaksoilla paikanpäällä tarkkaillen. Lehmiä havainnoitiin 3 kertaa 1,5 h ajan, yhteensä 36 tuntia. Lehmän sijainti kirjattiin 5 minuutin välein ja kahden lehmän välisiä sosiaalisia tapahtumia havainnoitiin jatkuvasti.

Säilörehun ruokintapaikan jakaminen ei vaikuttanut lehmien säilörehun syöntimääriin eikä maitotuotoksiin, mutta vähensi hieman syöntikertoja (10,7 vs 11,3 krt/vrk; P=0,12). Säilörehun syöntiin lehmät käyttivät $141 \mathrm{~min} / \mathrm{vrk}$ omalla ja $137 \mathrm{~min} /$ vrk jaetulla paikalla. Omalla paikalla lehmät seisoivat hieman pidempään, kuin jaetulla paikalla. Jaetun syöntipaikan lehmät käyttivät enemmän aikaa makaamiseen. Runsaampi väkirehuruokinta vähensi syödyn säilörehun määrää, syöntikertoja ja syöntipaikalla vietettyä aikaa. Vähemmän väkirehua saaneet lehmät söivät enemmän säilörehua ja seisoivat pidempään syöntipaikalla. Runsaammin väkirehua saaneet lehmät käyttivät säilörehun syönnistä vapautuneen ajan makaamiseen. Säilörehun syöntipaikan jakaminen lisäsi sosiaalisia yhteenottoja. Erityisesti ensikot olivat sosiaalisissa yhteenotoissa vanhempia lehmiä useammin aggressioita vastaanottavana osapuolena.

Hyvälaatuista säilörehua vapaasti tarjottaessa syöntipaikan jakaminen kolmen lehmän kesken ei vaikuta tuotoksiin tai säilörehun syöntiin, mutta lisää lehmien välisiä sosiaalisia yhteenottoja, etenkin ensikoilla. Ruokintapaikan jakamisen vaikutukset syöntikäyttäytymiseen olivat kokeessamme vähäiset, joskin jaettu paikka hieman vähensi syöntikertoja sekä syöntipaikalla seisomista. Voimakkaampi väkirehuruokinta jätti lehmille enemmän aikaa makaamiseen. Vaakakuppipaikalla lehmä saa syödä varsin rauhassa, joten tulosten tulkinnassa on huomioitava, että kokeemme tulokset eivät ole sovellettavissa avoimeen ruokintapöytään.

Asiasanat: lehmä, ruokintapaikka, säilörehu, väkirehu, poikimakerta, käyttäytyminen 


\section{Johdanto}

Maidontuotantoyksiköiden koko kasvaa nopeasti. Navetoiden suunnittelussa on huomioitava monia näkökulmia, kuten toiminnallisuus rehujen jaossa ja lannankäsittelyssä, eläinten ja hoitajien hyvinvointi sekä kustannukset. Useissa pihattoratkaisuissa kaikki lehmät eivät mahdu syömään samaan aikaan eli ne poikkeavat selvästi perinteisistä parsinavetoista, joissa lehmät ovat koko ajan kytkettyinä omaan ruokintapaikkaansa. Lehmillä on kuitenkin luontainen taipumus syödä yhtä aikaa (Bouissou ym., 2001), joten varsinkin heti uuden rehun jaon jälkeen ruokintapöydällä on tungosta (DeVries ym., 2005; Miller ja Wood-Gush, 1991). Tämä voi johtaa arvoasteikossa alempana olevien lehmien syönnin häiriintymiseen (DeVries ja von Keyserlingk, 2006). Lehmän iällä on vaikutusta sen sosiaaliseen asemaan, joten ensikot todennäköisesti kärsivät ruokintapaikkojen vähyydestä vanhempia lehmiä enemmän (Bouissou ym., 2001; DeVries ja von Keyserlingk, 2006).

Tutkimme, vaikuttaako ruokintapaikan jakaminen kerran poikineiden ja vanhempien lehmien käyttäytymiseen, syöntiin tai tuotantoon. Ruokintapöytäpaikan ohella selvitimme, vaikuttaako väkirehun osuuden lisääminen dieetissä ruokintapöytäpaineeseen ja lehmien käyttäytymiseen.

\section{Aineisto ja menetelmät}

Tutkimus tehtiin yhdessä 42 lehmän osastossa MTT:n (Maa- ja elintarviketalouden tutkimuskeskus) Minkiön tutkimuspihatossa Jokioisissa kevättalvella 2009. Kokeen syönti- ja tuotososassa oli kaikkiaan 36 ay-lehmää, joista 12 oli ensikoita ja 24 useamman kerran poikineita. Käyttäytymistarkkailuosaan otettiin mukaan kaikki osaston lehmät. Koe tehtiin kahdessa neljän viikon pituisessa jaksossa. Kummankin jakson ensimmäiset kolme viikkoa olivat sopeutumisviikkoja ja jakson viimeinen viikko oli aineiston keruu- ja tarkkailuviikko, jonka tietoja käytettiin tulosten laskennassa.

Lehmät oli jaettu 12 kolmen lehmän ryhmään, joista jokaisessa oli yksi ensikko, yksi 2 kertaa ja yksi 3 kertaa poikinut lehmä. Puolet koelehmistä eli 18 lehmää (yhteensä kuusi ryhmää) oli koko kokeen ajan alhaisemmalla ja puolet runsaammalla väkirehuruokinnalla. Alhaisemmalla väkirehuruokinnalla ensikot saivat väkirehua $9,5 \mathrm{~kg} / \mathrm{pv}$ ja vanhemmat lehmät $11,5 \mathrm{~kg} / \mathrm{pv}$. Runsaammalla väkirehuruokinnalla oli ensikoiden väkirehuannos $13,5 \mathrm{~kg} / \mathrm{pv}$ ja vanhempien lehmien 16,5 kg/pv. Säilörehua kaikki lehmät saivat vapaasti. Puolella lehmistä kummallakin väkirehunruokintatasolla oli säilörehun syöntiin jaksolla yksi oma ruokintapaikka ja puolella oli yhteinen paikka oman ryhmän kahden muun lehmän kanssa. Jaksolla kaksi ne lehmät, joilla jaksolla yksi oli oma ruokintapaikka, jakoivat paikan oman ryhmän muiden lehmien kanssa ja jaksolla yksi yhteisellä paikalla olleet saivat omat ruokintapaikat jaksolla kaksi.

Kotoinen väkirehu sisälsi (g/kg) ohraa (293), kauraa (270), leikettä (130), rypsipuristetta (280) ja kivennäisiä ja vitamiineja (27). Väkirehuannoksestaan lehmät saivat väkirehuautomaateista 75 \% ja lypsypaikalta $25 \%$. Väkirehunjakojaksoja oli viisi päivässä. Hyvälaatuista ensimmäisen sadon nurmisäilörehua oli vapaasti tarjolla kaikille lehmille. Säilörehun vapaan saannin turvaamiseksi tähteen määrä tuli olla vähintään $5 \%$ annetusta annoksesta. Säilörehu jaettiin neljänä annoksena päivässä.

Jaksojen viimeisellä viikolla otettiin

säilörehusta päivittäin ja väkirehusta kolmena päivänä osanäytteet, jotka yhdistettiin jaksonäytteiksi analyysejä varten. Säilörehusta analysoitiin $\mathrm{pH}$, kuiva-aine, tuhka, raakavalkuainen, NDF, in vitro -sellulaasisulavuus, liukoinen $\mathrm{N}$, ammonium-N, pelkistävät sokerit, maitohappo ja VFA. Väkirehunäytteistä määritettiin kuiva-aine, tuhka, raakarasva, raakavalkuainen ja NDF. Analyysit tehtiin MTT:n laboratoriossa standardimenetelmin. Väkirehun ja säilörehun kemiallinen koostumus ja rehuarvot on esitetty Taulukossa 1.

Lehmien maitomäärät rekisteröitiin jokaiselta lypsykerralta. Maitonäytteet otettiin jaksojen viimeisellä viikolla neljältä lypsykerralta. Maitonäytteistä määritettiin rasva, valkuainen ja laktoosi. Rehujen syöntimäärät määritettiin eläinkohtaisesti päivittäin. Väkirehun syöntimäärät kirjautuivat automaattisesti kioskeista (Pellonpaja Oy, Suomi) ja säilörehu syöntimäärät sekä syöntikerrat ja -ajat karkearehun ruokintapaikkojen vaakakupeilta (Ric-järjestelmä, Insentec, Hollanti). 
Taulukko 1. Rehujen kemiallinen koostumus ja rehuarvot.

\begin{tabular}{lll}
\hline & Säilörehu $^{1}$ & Väkirehu \\
\hline Kuiva-aine, g/kg & 231 & 895 \\
Kuiva-aineessa, g/kg & & \\
$\quad$ Tuhka & 86,1 & 72,7 \\
$\quad$ Raakavalkuainen & 146 & 183 \\
$\quad$ NDF & 516 & 249 \\
In vitro D-arvo, \% & 67,8 & \\
Rehuarvot & & \\
$\quad$ Ry/ kg ka & 0,93 & 1,06 \\
OIV, g/kg ka & 83,5 & 115 \\
PVT, g/kg ka & 3,5 & $-0,2$ \\
\hline
\end{tabular}

${ }^{1} \mathrm{pH}$ 3,93, sokeri 35 g/kg ka, maitohappo 55 g/kg ka, etikkahappo 20 g/kg ka, propionihappo 0,17 g/kg ka, voihappo 0,09 g/kg ka, ammonium-N 42 g/kg N, liukoinen-N 485 g/kg N.

Eläinten käyttäytymistä rekisteröitiin molempien jaksojen viimeisellä viikolla neljänä päivänä. Käyttäytymistarkkailuun otettiin siis mukaan kaikki koeosaston 42 lehmää, myös ne kuusi lehmää, jotka eivät olleet mukana kokeen muissa osioissa. Tarkkailu tehtiin suorana tarkkailuna paikan päällä. Käyttäytymistarkkailua teki samanaikaisesti kaksi ihmistä, yksi kummallakin puolella ruokintapöytää, väkirehukioskien päälle sijoitetuilta lavoilta. Tarkkailua tehtiin kolme kertaa vuorokaudessa, 1,5 tunnin ajan kerrallaan, säilörehun jaosta alkaen. Tarkkailutunteja oli kaikkiaan 36. Menetelmänä käytettiin sekä jatkuvaa että jaksoittaista seurantaa. Lehmän sijainti havainnoitiin viiden minuutin välein (lehmä seisoo: omalla ruokakupilla, vieraalla ruokakupilla, oman ruokakupin lähellä, käytävällä, lähellä väkirehukioskia, väkirehukioskissa, vesikupilla, parressa sekä lehmä makaa makuuparressa). Kaikki seisomishavainnot myös yhdistettiin jälkeenpäin, jotta saatiin selville lehmien seisomishavaintojen kokonaismäärä.

Kahden lehmän välisiä sosiaalisia tapahtumia havainnoitiin jatkuvasti. Näihin tapahtumiin luokiteltiin: lehmän syrjäyttäminen ruokakupilta, lehmän syrjäyttäminen vesikupilta, uhkaaminen, puskeminen, nuoleminen, häirintä väkirehukioskilla, taisteleminen, leuan pitäminen toisen lehmän selän päällä, toisen lehmän selkään hyppiminen ja kielenpyöritys. Kielenpyöritystä lukuun ottamatta tapahtumista havainnoitiin aktiivinen ja passiivinen osapuoli. Havainnot yhdistettiin analyysivaiheessa aggressiivisen käyttäytymisen tapahtumiksi (syrjäyttäminen ruokakupilta, syrjäyttäminen vesikupilta, uhkaaminen, puskeminen, häirintä väkirehukioskilla ja taisteleminen), nuolemistapahtumiksi ja seksuaalisen käyttäytymisen tapahtumiksi (leuan pitäminen toisen lehmän selän päällä ja toisen lehmän selkään hyppiminen).

\section{Tilastolliset analyysit}

Koeaineiston tilastollinen analysointi perustui cross-over koeasetelmaan, minkä vuoksi malli sisälsi jakson, lehmän, väkirehunruokintatason, varsinaisen käsittelyn (oma/yhteinen ruokintapaikka) ja käsittely x väkirehunruokintataso -vaikutukset. Kokeessa oli lisäksi eri-ikäisiä eläimiä, joten malliin lisättiin sekä poikimakerran päävaikutus että seuraavat yhdysvaikutukset: poikimakerta $\mathrm{x}$ väkirehunruokintataso, poikimakerta $\mathrm{x}$ käsittely ja poikimakerta $\mathrm{x}$ käsittely $\mathrm{x}$ väkirehunruokintataso. Lehmät oli jaettu 12 kolmen lehmän ryhmään. Ryhmä otettiin malliin mukaan, mutta sen vaikutus ei ollut tilastollisesti merkitsevä, joten se jätettiin lopullisesta mallista pois. Tilastollinen analysointi tehtiin SAS/MIXEDohjelmalla.

\section{Tulokset ja tulosten tarkastelu Tuotokset ja syönnit}

Poikimakerran, ruokintapaikan ja väkirehunruokintatason välillä ei tilastollisissa analyyseissä todettu merkitseviä yhdysvaikutuksia koskien tuotos- ja syöntituloksia. Tämän vuoksi syönnit ja tuotokset on esitetty taulukoissa 2 ja 3 faktoreittain ruokintapaikan ja väkirehuruokintatason osalta. Syönti- ja tuotostuloksia ei esitetä poikimakerroittain, sillä kuten muissakin tutkimuksissa, niin myös meidän kokeessamme ensikot söivät (19,7 vs. 23,9 kg ka/pv) ja lypsivät (30,5 vs. 37,2 kg EKM/pv) vähemmän kuin useamman kerran poikineet lehmät. 
Säilörehun ruokintapaikan jakaminen kahden muun lehmän kanssa ei vaikuttanut lehmien maitotuotoksiin tai maidon pitoisuuksiin. Omalla ruokintapaikalla keskimääräinen energiakorjattu maitotuotos oli 35,1 kg/pv ja jaetulla paikalla 34,8 kg/pv (Taulukko 2). Säilörehun syönti jaetulla ruokintapaikalla ei vaikuttanut myöskään säilörehun syöntimääriin tai kokonaissyöntiin (Taulukko 3).

Taulukko 2. Säilörehun ruokintapaikan jakamisen ja dieetin väkirehutason vaikutus koelehmien keskimääräisiin maitotuotoksiin ja maidon koostumukseen.

\begin{tabular}{|c|c|c|c|c|c|c|c|}
\hline & \multicolumn{3}{|c|}{ Sälörehun ruokintapaikka } & \multicolumn{3}{|c|}{ Dieetin väkirehutaso } & \multirow[b]{2}{*}{$\mathbf{P}$} \\
\hline & Oma & Yhteinen & s.e. & $\begin{array}{l}\text { Alhai- } \\
\text { sempi }\end{array}$ & $\begin{array}{l}\text { Run- } \\
\text { saampi }\end{array}$ & s.e. & \\
\hline \multicolumn{8}{|c|}{ Tuotokset, kg/pv } \\
\hline Maito & 34,5 & 34,2 & 0,78 & 33,9 & 35,0 & 0,63 & \\
\hline EKM & 35,1 & 34,8 & 0,48 & 34,3 & 35,6 & 0,62 & \\
\hline Rasva & 1,43 & 1,43 & 0,025 & 1,41 & 1,44 & 0,031 & \\
\hline Valkuainen & 1,16 & 1,15 & 0,016 & 1,12 & 1,19 & 0,022 & $*$ \\
\hline Laktoosi & 1,60 & 1,58 & 0,024 & 1,56 & 1,62 & 0,032 & \\
\hline \multicolumn{8}{|c|}{ Maidon pitoisuudet, \% } \\
\hline Rasva & 4,15 & 4,18 & 0,066 & 4,19 & 4,14 & 0,086 & \\
\hline Valkuainen & 3,36 & 3,37 & 0,028 & 3,32 & 3,41 & 0,038 & \\
\hline Laktoosi & 4,61 & 4,61 & 0,018 & 4,59 & 4,63 & 0,025 & \\
\hline
\end{tabular}

EKM= energiakorjattu maitotuotos.

Taulukko 3. Säilörehun ruokintapaikan jakamisen ja dieetin väkirehutason vaikutus koelehmien keskimääräisiin syönteihin.

\begin{tabular}{|c|c|c|c|c|c|c|c|}
\hline & \multicolumn{3}{|c|}{ Sälörehun ruokintapaikka } & \multicolumn{3}{|c|}{ Dieetin väkirehutaso } & \multirow[b]{2}{*}{$\mathbf{P}$} \\
\hline & Oma & Yhteinen & s.e. $\quad \mathbf{P}$ & $\begin{array}{l}\text { Alhai- } \\
\text { sempi }\end{array}$ & $\begin{array}{l}\text { Run- } \\
\text { saampi }\end{array}$ & s.e. & \\
\hline \multicolumn{8}{|l|}{ Syönti, kg ka/pv } \\
\hline Väkirehu & 11,6 & 11,5 & 0,09 & 9,6 & 13,4 & 0,10 & $* * *$ \\
\hline Säilörehu & 10,9 & 11,1 & 0,22 & 12,0 & 10,0 & 0,29 & $* * *$ \\
\hline Yhteensä & 22,5 & 22,5 & 0,24 & 21,6 & 23,4 & 0,31 & $* * *$ \\
\hline Raakavalkuainen, kg/pv & 3,70 & 3,71 & 0,04 & 3,50 & 3,90 & 0,05 & $* * *$ \\
\hline $\mathrm{Ry} / \mathrm{pv}$ & 22,3 & 22,4 & 0,22 & 21,3 & 23,5 & 0,29 & $* * *$ \\
\hline $\mathrm{OIV}, \mathrm{kg} / \mathrm{pv}$ & 2,24 & 2,24 & 0,02 & 2,11 & 2,38 & 0,03 & $* * *$ \\
\hline Väkirehu, \% ka:sta & 51,3 & 50,8 & 0,50 & 44,7 & 57,3 & 0,65 & $* * *$ \\
\hline EKM/ry & 1,51 & 1,56 & 0,023 & 1,61 & 1,52 & 0,031 & $*$ \\
\hline $\begin{array}{l}\text { Maitovalkuainen/ } \\
\text { rehuvalkuainen, g/g }\end{array}$ & 0,32 & 0,31 & 0,005 & 0,32 & 0,31 & 0,006 & \\
\hline
\end{tabular}

Dieetin väkirehupitoisuus kuiva-aineesta oli runsaammalla väkirehuruokinnalla 57,3 \% ja alhaisemmalla 44,7 \%. Keskimäärin lehmät runsaammalla väkirehuruokinnalla söivät 3,8 kg väkirehun kuiva-ainetta päivässä enemmän, kuin alhaisemmalla väkirehuruokinnalla. Runsaampi väkirehuruokinta vähensi lehmien säilörehun syöntiä, mutta lisäsi kokonaiskuiva-aineen syöntiä (Taulukko 3). Korvaussuhde eli säilörehun syönnin väheneminen väkirehun saannin lisääntyessä 1 kilolla oli 0,53. Tämä vastaa hyvin aikaisemmissa tutkimuksissa saatuja tuloksia (Huhtanen ym., 2008).

Lehmien energian ja valkuaisen saanti oli lisääntyneestä syönnistä ja suuremmista väkirehuannoksista johtuen suurempi runsaammalla, kuin alhaisemmalla väkirehuruokinnalla. Maitotuotoksia runsaampi väkirehun saanti ei kuitenkaan merkitsevästi lisännyt, runsaammin väkirehua saaneet lehmät lypsivät energiakorjattua maitoa 35,6 kg/pv ja vähemmän saaneet 34,3 kg/pv (Taulukko 2). Lisääntynyt energian ja OIV-saanti runsaammalla väkirehuruokinnalla sen sijaan lisäsi merkitsevästi valkuaistuotosta. 


\section{Säilörehun syöntikäyttäytyminen}

Ruokintapaikan jakaminen kahden muun lehmän kanssa ei merkitsevästi vaikuttanut lehmien säilörehun syöntikäyttäytymiseen (Taulukko 4). Säilörehun syöntiin käytettiin päivittäin keskimäärin 140 minuuttia. Yhden syöntikerran kesto oli keskimäärin 13,1 minuuttia. Ensikoiden ja vanhempien lehmien välillä ei ollut eroa säilörehun syöntiin käytetyssä ajassa. Tulokseemme voi vaikuttaa se, että vaakakuppipaikka on varsin hyvin suojattu paikka syödä. Syönnin aikainen pään suojaaminen on Bouissou ym., (2001) mukaan osoittautunut parhaaksi keinoksi lisätä sosiaalisessa asemassa alhaisempien lehmien ruokailuaikaa. Miettisen (2008) tutkimuksessa, jossa lehmät ruokailivat samanlaisilla vaakakupeilla, kuin meidän tutkimuksessamme, ensikot käyttivät jopa enemmän aikaa säilörehun syöntiin kuin vanhemmat lehmät (199 vs. $153 \mathrm{~min} / \mathrm{pv}$ ). Heidän tutkimuksessaan lehmiä oli kaksinkertainen märä syöntipaikkoihin verrattuna. Tässä ja Miettisen (2008) tutkimuksessa pihatto-olosuhteissa mitatut syöntiajat säilörehulle ovat huomattavasti lyhyempiä kuin parsinavetassa mitatut säilörehun syöntiajat (277 ja 260 min/vrk) Rinteen ym. (1999) ja Shingfieldin ym. (2002) tutkimuksessa.

Jaetulla ruokintapaikalla lehmät vierailivat keskimäärin 10,7 kertaa päivässä, kun omalla ruokintapaikalla käytiin syömässä keksimäärin 11,3 kertaa päivässä $(\mathrm{P}=0,12)$. Syöntikertojen määrässä ei ensikoiden ja vanhempien lehmien välillä ollut eroja. Säilörehun syöntinopeudessa ei ollut eroa omalla tai jaetulla paikalla syötäessä ( 0,354 vs. $0,366 \mathrm{~kg} / \mathrm{min} ; \mathrm{P}=0,13)$. Poikimakerta vaikutti suuntaa antavasti säilörehun syöntinopeuteen; vanhemmat lehmät söivät säilörehua hieman nopeammin kuin ensikot (0,384 vs. 0,318 kg/min; $\mathrm{P}=0,08$ ). Yhtenevästi Miettisen (2008) tutkimuksessa vanhempien lehmien säilörehun syöntinopeus oli ensikoiden syöntinopeutta suurempi.

Säilörehun syöntikäyttäytymishavaintojen perusteella runsaampi väkirehuruokinta vähensi painetta säilörehun ruokintapaikalla. Se vähensi säilörehun syönnin lisäksi syöntikertoja ja syöntipaikalla vietettyä aikaa (Taulukko 4). Vähemmän väkirehua saaneet lehmät käyttivät keskimäärin 45 min enemmän aikaa säilörehun syöntiin päivässä kuin runsaammalla väkirehuruokinnalla olleet lehmät. Säilörehun kertasyöntimäärien osalta oli ruokintapaikkatilan ja väkirehun ruokintatason välillä yhdysvaikutus. Alhaisemmalla väkirehutasolla ei kertasyöntimäärissä ollut eroa omalla tai yhteisellä syöntipaikalla ruokailleilla lehmillä. Runsaammalla väkirehutasolla lehmät, joilla oli oma syöntipaikka, söivät säilörehua kerralla 4,6 kg ja lehmät, joilla oli yhteinen paikka, söivät kerralla 5,0 kg (P=0,04).

Taulukko 4. Säilörehun ruokintapaikan rajoittamisen ja dieetin väkirehutason vaikutus koelehmien säilörehun syöntikäyttäytymiseen.

\begin{tabular}{|c|c|c|c|c|c|c|c|c|}
\hline \multirow[b]{2}{*}{ Säilörehun syönti } & \multicolumn{4}{|c|}{ Sälörehun ruokintapaikka } & \multicolumn{3}{|c|}{ Dieetin väkirehutaso } & \multirow[b]{2}{*}{$\mathbf{P}$} \\
\hline & Oma & Yhteinen & s.e. & $\mathbf{P}$ & $\begin{array}{l}\text { Alhai- } \\
\text { sempi }\end{array}$ & $\begin{array}{l}\text { Run- } \\
\text { saampi }\end{array}$ & s.e. & \\
\hline Syöntiaika, min/pv & 141 & 137 & 5,2 & & 162 & 117 & 6,7 & $* * *$ \\
\hline Syöntikerrat, krt/pv & 11,3 & 10,7 & 0,4 & & 12,3 & 9,7 & 0,5 & $* *$ \\
\hline Syöntimäärä, kg/krt & 4,5 & 4,6 & 0,17 & $--^{1}$ & 4,3 & 4,8 & 0,23 & $--^{1}$ \\
\hline Syönninkesto, min/krt & 13,1 & 13,1 & 0,59 & & 13,6 & 12,6 & 0,74 & \\
\hline Syöntinopeus, kg/min & 0,354 & 0,366 & 0,014 & & 0,324 & 0,396 & 0,019 & $*$ \\
\hline
\end{tabular}

${ }^{1}$ Ruokintapaikka väkirehutaso yhdysvaikutus; Alhaisemmalla väkirehutasolla ei eroa kertasyönneissä omalla ja yhteisellä syöntipaikalla. Runsaammalla väkirehutasolla lehmät söivät säilörehua omalla syöntipaikalla 4,6 $\mathrm{kg} / \mathrm{krt}$ ja yhteisellä 5,0 kg/krt (P=*).

\section{Lehmän sijainti}

Ruokintapaikan kahden muun lehmän kanssa jakaneet seisoivat hieman vähemmän omalla ruokintapaikallaan ( 13 vs. $15 \%$ havainnoista, $\mathrm{P}=0,10$ ), mutta toisaalta makasivat hieman enemmän (60 vs. 56 \% havainnoista, $\mathrm{P}=0.10$ ), kuin ne lehmät, joilla oli oma ruokintapaikka. Lepo on lehmän hyvinvoinnille ensisijaisen tärkeää (Munksgaard ym., 2005), joten seisomisen kompensoiminen levolla voi olla positiivista lehmän hyvinvoinnille.

Ensikot seisoivat 2- ja 3-kertaa poikineita lehmiä enemmän väkirehukioskin lähellä (7 \% vs. 6 \% ja $5 \%$ havainnoista, $\mathrm{P}=0,05$ ). Tämä voi liittyä ensikoiden heikompaan sosiaaliseen asemaan (Bouissou ym., 2001), jonka vuoksi ne voivat joutua väkirehukioskille pyrkiessään väistämään vanhempia, arvoltaan ylempiä lehmiä ja siten odottamaan kauemmin väkirehukioskille pääsyä (DeVries ja von Keyser- 
lingk, 2006). Kolme kertaa poikineet lehmät sen sijaan seisoivat hieman enemmän parressa kuin ensikot ja 2-kertaa poikineet (8 \% vs. $6 \%$ ja $6 \%$ havainnoista, $\mathrm{P}=0,07$ ).

Poikimakerran ja dieetin väkirehutason välillä havaittiin lehmän makaamiseen liittyvä yhdysvaikutus. Kaksi kertaa poikineista lehmistä omalla kupilla ruokailleet makasivat jostain syystä vähemmän, kuin kahden muun kanssa ruokintapaikan jakaneet lehmät (54 \% vs. 66 \% havainnoista, $\mathrm{P}=0,07)$. Väkirehutasolla oli selkeitä vaikutuksia lehmien sijaintiin. Runsaammalla väkirehudieetillä olleet lehmät seisoivat vähemmän omalla ruokakupilla ja makasivat enemmän, kuin alhaisemmalla väkirehudieetillä olleet lehmät (seisominen omalla ruokakupilla $11 \%$ vs. $17 \%, \mathrm{P}<0,001$; makaaminen $62 \%$ vs. 53 \% havainnoista, $\mathrm{P}=0,02)$. Dieetin väkirehutaso siis ohjaa lehmän käyttäytymistä navetassa.

\section{Sosiaaliset tapahtumat}

Havaitsimme tarkkailujen aikana yhteensä 833 kahden lehmän välistä sosiaalista tapahtumaa. Aggressiivisiksi luokiteltuja tapahtumia (syrjäyttäminen ruokakupilta, syrjäyttäminen vesikupilta, uhkaaminen, puskeminen, häirintä väkirehukioskilla ja taisteleminen) havaittiin 600, nuolemistapahtumia 210 ja seksuaalisen käyttäytymisen tapahtumia 23. Kielenpyöritystapahtumia havaittiin koko aikana 23, joista yli puolesta vastasi yksi lehmä pyörittäen kieltä ollessaan sekä omalla että jaetulla ruokintapaikalla. Kaiken kaikkiaan viiden eri lehmän havaittiin pyörittävän kieltä.

Ruokintapaikan kahden muun lehmän kanssa jakaneet olivat enemmän sekä aktiivisia (15 vs. 11 tapahtumaa/lehmä, $\mathrm{P}=0.05$ ) että passiivisia (16 vs. 10 tapahtumaa/lehmä, $\mathrm{P}<0,01$ ) aggressiivisissa yhteenotoissa, kuin omalla ruokintapaikalla olleet. Tulos on yhtenevä Olofssonin (1999) tulosten kanssa. Hänen kokeessaan syrjäyttämiset ruokintapaikalla lisääntyivät huomattavasti, kun lehmät jakoivat paikan kolmen muun lehmän kanssa verrattuna tilanteeseen, jossa lehmällä oli oma paikka. Lehmän poikimakerralla oli suuri vaikutus havaittujen aggressiivisten tapahtumien määrään (Kuva 1). Ensikot olivat aggressiivisissa yhteenotoissa eniten vastaanottajia $(\mathrm{P}<0,01)$ ja vähiten aktiivisia $(\mathrm{P}=0,05)$, mikä todennäköisesti liittyy ensikoiden vanhempia lehmiä heikompaan sosiaaliseen asemaan (Bouissou ym., 2001; DeVries ja von Keyserlingk, 2006).

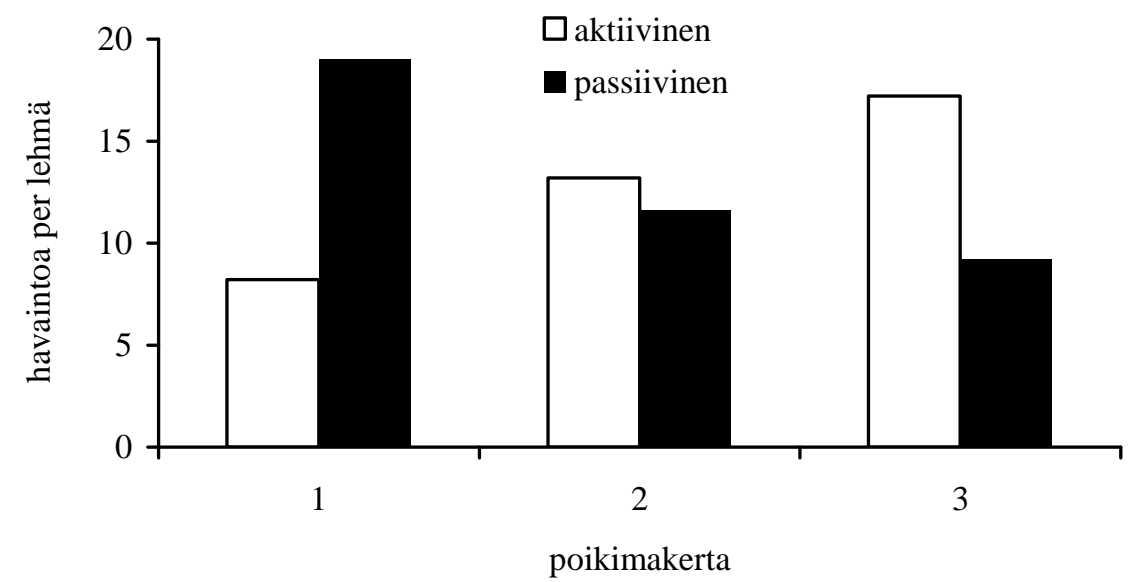

Kuva 1. Lehmien aggressiiviset sosiaaliset yhteenotot (syrjäyttäminen ruokakupilta, syrjäyttäminen vesikupilta, uhkaaminen, puskeminen, häirintä väkirehukioskilla ja taisteleminen) tapahtumaan osallistuneen lehmän aktiivisuuden (aktiivinen tai passiivinen) ja poikimakerran (1-, 2- ja 3 kertaa poikineet) mukaan.

\section{Johtopäätökset}

Hyvälaatuista säilörehua vapaasti tarjottaessa syöntipaikan jakaminen kolmen lehmän kesken ei vaikuta tuotoksiin, säilörehun syöntimääriin tai - syöntiaikaan, mutta lisää lehmien välisiä sosiaalisia yhteenottoja, josta etenkin ensikot kärsivät. Ruokintapaikan jakamisen vaikutukset syöntikäyttäytymiseen ovat vähäiset, joskin jaettu paikka hieman vähentää lehmien päivittäisiä syöntikertoja sekä säilörehukupilla seisomista. Yleisesti lehmät sopeutuivat ruokintapaikan jakamiseen melko hyvin.

Voimakkaampi väkirehuruokinta jättää lehmille enemmän aikaa makaamiseen, kun alhaisemmalla väkirehuruokinnalla olleet lehmät syövät säilörehua pidempään, enemmän ja useammin. Ko- 
keessamme ruokintapöytäpainetta vähensi väkirehuannoksen tarjoaminen kioskeista, mutta seosrehuruokinnalla on huomattava, että ruokintapöytäpaine on suurempi. Kokeessamme käytetyllä vaakakuppipaikalla lehmä saa syödä varsin rauhassa, joten tulosten tulkinnassa on syytä huomata, että tuloksemme eivät ole sovellettavissa esimerkiksi avoimeen niskapuomilliseen ruokintapöytään.

\section{Kirjallisuus}

Bouissou, M.F., Boissy, A., Le Neindre, P. \& Veissier, I. 2001. The Social Behaviour of Cattle. Teoksessa: Keeling, L.J. \& Gonyou, H.W. (toim.) Social Behaviour in Farm Animals. s. 113-145. CABI Publishing: Wallingford, UK.

Huhtanen, P., Rinne, M. \& Nousiainen, J. 2008. Evaluation of concentrate factors affecting silage intake of dairy cows: a development of the relative total diet intake index. Animal 2: 942-935.

Miller, K. \& Wood-Gush, D.G.M. 1991. Some effects of housing on the social behaviour of dairy cows. Anim. Prod. 53: 271-278.

Miettinen, N. 2008. Ensikoiden säilörehun syöntikäyttäytyminen automaattisen lypsyjärjestelmän pihatossa. Pro Gradu-tutkielma.

Munksgaard, L., Jensen, M.B., Pedersen, L.J., Hansen, S.W. \& Matthews, L. 2005. Quantifying behavioural priorities - effects of time constraints on behaviour of dairy cows, Bos taurus. Appl. Anim. Behav. Sci. 92: 3-14. DeVries, T.J. \& von Keyserlingk, M.A.G. 2006. Feed Stalls Affect the Social and Feeding Behaviour of Lactating Dairy Cows. J. Dairy Sci. 89: 3522-3531.

Olofsson, J. 1999. Competition for Total Mixed Diets Fed for Ad Libitum Intake Using One or Four Cows per Feeding Station. J. Dairy Sci. 82: 69-79.

Rinne, M. Jaakkola, S., Kaustell, K., Heikkilä, T. \& Huhtanen, P. 1999. Silage harvested at different stage of grass growth v. concentrate foods as energy and protein source in milk production. Animal Science 69: 251-263.

Shingfield, K. Jaakkola, S. \& Huhtanen, P. 2002. Effect of forage conservation method, concnetrate level and prpylene glycol on intake, feeding behaviour and milk production of dairy cows. Animal Science 74: 383-397.

Wierenga, H.K. \& Hopster, H. 1991. Behaviour of dairy cows when fed concentrates with an automatic feeding system. Appl. Anim. Behav. Sci. 30: 223-246. 